\title{
安静時ラット骨格筋の遊離脂肪酸利用に対する ブドウ糖，インスリンの影響
}

東京慈恵会医科大学第三内科学教室, 同健康医学科*

大 橋 力, 成 宮 学, 窪 倉 俊 隆, 鏑 木 與 善,
染 谷 泰 寿, 田 嶼 尚子, 池 田 義 雄*, 磯 貝 行 秀

The Effects of Insulin and Glucose on the Utilization of Non-esterified Fatty Acid in the Resting Rat Skeletal Muscle

\section{Tsutomu OHASHI, Manabu NARIMIYA, Toshitaka KUBOKURA, Motoyoshi KABURAKI, Yasuhisa SOMEYA, Naoko TAJIMA, Yoshio IKEDA* and Yukihide ISOGAI}

Third Department of Internal Medicine, The Jikei University School of Medicine,

*Department of Preventive Medicine, The Jikei University School of Medicine

The present study was undertaken to clarify the effects of insulin and glucose on the utilization of nonesterified fatty acid (NEFA) in the resting rat skeletal muscle using the perfusion technique. The 24hr-starved and non-starved rat hind limbs were perfused for one hour with the perfusion mediums containing $1 \mathrm{mM}$ palmitate and various concentrations of glucose and insulin, and sampling was performed to calculate the clearance of NEFA (F value). In the absence of glucose, the F value of the starved rat hind limb was less than that of the nonstarved rats, independently of insulin concentrations $(0$ and $125 \mu \mathrm{U} / \mathrm{ml})$ in the perfusion medium $(\mathrm{p}<0.02)$. Moreover, there was no influence of insulin on the $\mathrm{F}$ value in both the starved and the non-starved groups. In the presence of $13.9 \mathrm{mM}$ glucose, there were no statistically significant differences in the $\mathrm{F}$ value without insulin between the non-starved and starved groups. However, the F value was increased in the presence of 62.5 or 125 $\mu \mathrm{U} / \mathrm{ml}$ insulin, compared with that in the absence of insulin $(\mathrm{p}<0.001)$, although when the insulin concentration was elevated to $500 \mu \mathrm{U} / \mathrm{ml}$, it was decreased. Both in the non-staved and the starved groups indepedently of insulin concentrations, the $\mathrm{F}$ value in the glucose-added condition was increased, compared with that in the absence of glucose. These results indicated that the utilization of NEFA in the resting rat sleletal muscle was facilitated by the moderate supply of glucose, although it was suppressed by the presence of abundant glucose.

Keywords: skeletal muscle, insulin, glucose, NEFA utilization

\section{は じめ に}

脂肪酸は安静時骨格筋の主要なエネルギー源として利用されている。Randleら ${ }^{1} は$, 脂肪酸の酸化が光進 することにより，ブドウ糖利用が抑制されることを報告した。以来，骨格筋をはじめとするインスリン感受 性組織における，脂肪酸とブドウ糖利用の相互関係が注目されてきた。血中遊離脂肪酸（NEFA）濃度の上 
昇や，脂肪酸酸化の充進が，インスリン刺激によるブドウ糖利用を抑制することは多くの成績によって明ら かにされている2 まの。また，インスリン抵抗性の観点から，脂肪酸の酸化光進が，特に肥满を伴ったII型糖 尿病の成因の一つとなりうることも報告されている》。このように，骨格筋のブドウ糖利用に対するNEFA の影響については，詳細な検討が報告されているが，骨格筋におけるNEFA利用に対するブドウ糖やインス リン濃度の影響については，未だ十分な検討がなされていない。そこで，今回我々は，下肢潅流実験法を 用い，安静時ラット下肢骨格筋の脂肪酸利用に対するブドウ糖，インスリン濃度の影響について調べた。

\section{材料および方法}

\section{（1）実験動物}

実験には，体重 $250 \mathrm{~g}$ 前後の雄性Wistar系ラットを用いた。絶食群では，潅流開始24時間前より，非絶食 群は4時間前より絶食とし，飲水のみとした。

（2）ラット血中ブドウ糖, NEFA濃度の測定

潅流開始前にラット尾静脈より採血し，ヘキソキナーゼ法により血中ブドウ糖濃度を, 酵素法により血 清NEFA濃度を測定した。

\section{（3）潅流方法}

ラット腹腔内へ体重 $1 \mathrm{~kg}$ あたり $1 \mathrm{ml}$ のネンブタール（Abbott Laboratories, North Chicago, IL）を注射し麻 酔処理を行った後, Mondon ${ }^{8)}$ の方法に準じて下肢潅流実験を行った。ラット腹部正中切開施行後, 腸間 膜動静脈をはじめとする主要な腹部大動脈, 下大静脈の分枝血管を結紮し, 腎動脈上方で大動静脈を結紮 して, 尾側へむけて腹部大動脈, 大静脈へ各々カニュレーションを施行。潅流液を通して洗浄した後, 潅 流液量 $50 \mathrm{ml}$ の再潅流方式により, $5 \mathrm{ml} / \mathrm{min}$ の速さで 1 時間潅流を行った。

\section{（4）潅流液}

$3 \%$ ウシ血清アルブミン (Sigma Chemical Co., St. Louis, MO USA), 1mMパルミチン酸（Sigma Chemical Co.,）を含むKrebs-Ringer 重炭酸緩衝液とラット洗浄赤血球の混合液を基礎潅流液として用いた。 これに13.9mM となるようにブドウ糖を添加した群と非添加群にわけ，さらに添加群についてはインスリン 濃度 $0,62.5,125,500 \mu \mathrm{U} / \mathrm{ml}$ となるようにインスリン（Novolin R, Novo Nordisk Pharma Co., Denmark）を 加えた。また, 非添加群についてはインスリン添加群（125 $\mu \mathrm{U} / \mathrm{ml} ）$ と非添加群について潅流を行った。潅 流液は, $95 \% \mathrm{O}_{2}$ と $5 \% \mathrm{CO}_{2}$ で飽和し $37{ }^{\circ} \mathrm{C}$ に保った。

\section{（5）内因性NEFAの放出測定}

絶食群，非絶食群において，それぞれパルミチン酸を含まない同様の潅流液で下肢潅流実験を行い，内 因性NEFAの放出量を測定した。

\section{（6）下肢骨格筋におけるNEFA クリアランス值（F值）の算出}

潅流開始前と開始30 分後, 60分後に潅流液のサンプリングを行い, NEFA濃度を酵素法（NEFA-SS ‘栄 研’，栄研化学，東京）にて測定した。その結果より下記の式を用いてF值を算出した。

$\mathrm{F}(\mu \mathrm{l} / \mathrm{min} / \mathrm{g}$ muscle $)=\mathrm{NEFA}$ 㨫取量 $(\mathrm{mEq} / \mathrm{min} / \mathrm{g}$ muscle $) / \mathrm{NEFA}$ 濃度 $(\mathrm{mEq} / \mu \mathrm{l})$

さらに，上記の式より算出したF值を，前述の内因性NEFA放出の測定結果から補正した。

体重 $250 \mathrm{~g}$ 前後の雄性Wistar 系ラット下肢の組織組成は, 脂肪組織 $18 \%$, 骨組織 $12 \%$, 筋肉組織 $70 \%$ で あり，下肢潅流時の脂肪酸利用は，主に筋肉組織によるものであると考えられた。

以上の実験によって得られた成績の統計学的な分析はStudent's t-testを用いて行った。 
（1）潅流前ラット血中ブドウ糖およびNEFA濃度

潅流開始前の血中ブドウ糖濃度は非絶食群で $5.2 \pm 0.2 \mathrm{mM}$ (mean $\pm \mathrm{SEM}, \mathrm{n}=12)$, 絶食群で $3.8 \pm$ $0.2 \mathrm{mM}(\mathrm{n}=12)$ と有意に絶食群で低值を示した（ $\mathrm{p}<0.001 ） 。 一$ 方，NEFA濃度は，それぞれ $0.83 \pm 0.04$ $(\mathrm{n}=12), 1.32 \pm 0.04(\mathrm{n}=12) \mathrm{mEq} / \mathrm{l}$ と絶食群で有意に高值を示した $(\mathrm{p}<0.001)$ 。

（2）内因性NEFAの放出

絶食群における潅流下肢からの内因性NEFA放出は，ブドウ糖，インスリンともに非存在下で $1.32 \pm 0.12$ $\mu \mathrm{Eq} / \mathrm{hr} / \mathrm{g}$ muscle $(\mathrm{n}=7)$, ブドウ糖存在下では, インスリン濃度 $0,62.5,125,500 \mu \mathrm{U} / \mathrm{ml}$ の順に, $1.16 \pm$ $0.08(\mathrm{n}=8), 1.20 \pm 0.12(\mathrm{n}=7), 1.16 \pm 0.12(\mathrm{n}=7), 0.60 \pm 0.08 \mu \mathrm{Eq} / \mathrm{hr} / \mathrm{g}$ muscle $(\mathrm{n}=8)$ であった。イン スリン濃度 $500 \mu \mathrm{U} / \mathrm{ml}$ の潅流液で有意（p<0.05）に低值を示したが，他の群間に有意差は認めなかった。 また，非絶食群では，いずれの群も内因性NEFA放出は $0.40 \mu \mathrm{Eq} / \mathrm{hr} / \mathrm{g}$ muscle 以下であった。

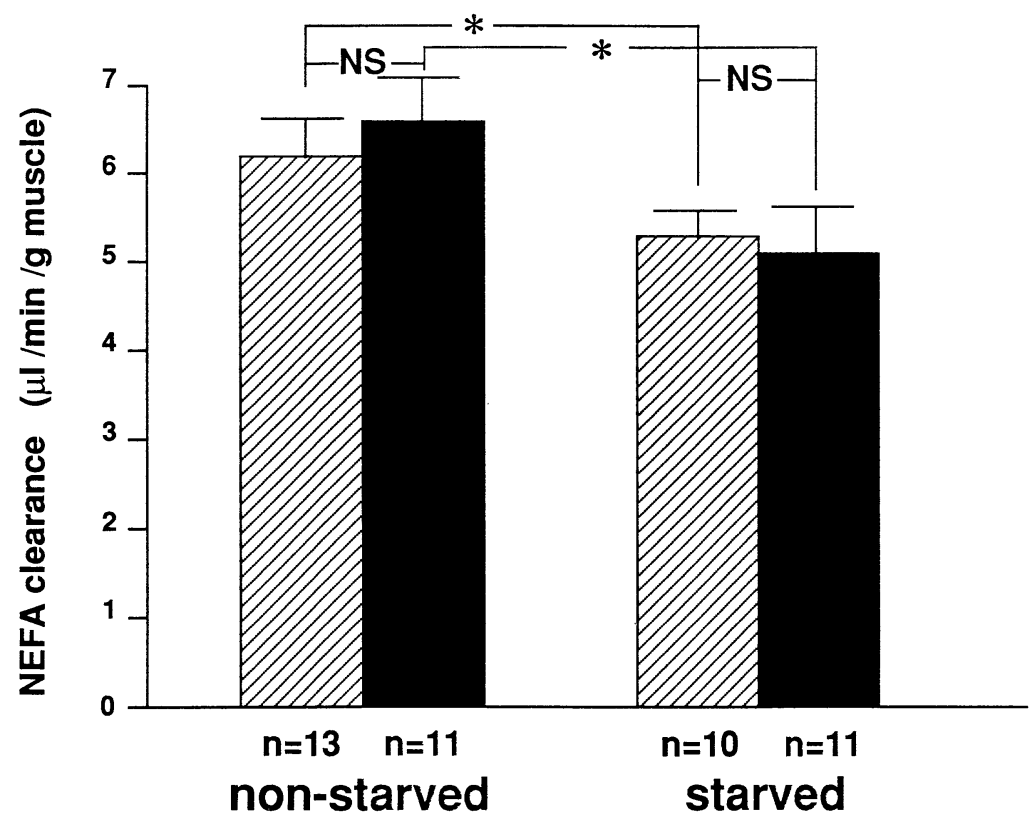

Fig. 1 The effect of starvation on NEFA utilization in the absence of glucose.

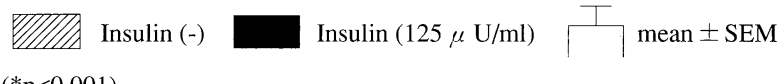

$\left({ }^{*} \mathrm{p}<0.001\right)$ 


\section{(3) F值}

ブドウ糖非添加潅流液では，非絶食群と絶食群のF値はそれぞれ，インスリン非存在下で， $6.2 \pm 0.3$, $5.3 \pm 0.2 \mu \mathrm{l} / \mathrm{min} / \mathrm{g}$ muscle, インスリン $125 \mu \mathrm{U} / \mathrm{ml}$ 存在下で, $6.6 \pm 0.4,5.1 \pm 0.4 \mu \mathrm{l} / \mathrm{min} / \mathrm{g}$ muscle と, イ ンスリンの有無にかかわらず絶食群で有意に低值を示した。また, F值に対するインスリンの影響は, 両群 ともに認められなかった（Fig.1）。ブドウ糖濃度 13.9mM の潅流液では，非絶食群のF值は，インスリン非 存在下，62.5, 125, $500 \mu \mathrm{U} / \mathrm{ml}$ 存在下でそれぞれ7.6 $\pm 0.2 \quad(\mathrm{n}=11), 9.4 \pm 0.2 \quad(\mathrm{n}=9), 8.0 \pm 0.3 \quad(\mathrm{n}=11)$,


( $\mathrm{n}=12), 9.2 \pm 0.4$ ( $\mathrm{n}=12), 7.0 \pm 0.2 \mu \mathrm{l} / \mathrm{min} / \mathrm{g}$ muscle（ $\mathrm{n}=15 ）$ であった。インスリン非存在下に比較して, 非絶食群ではインスリン濃度 $62.5 \mu \mathrm{U} / \mathrm{ml}$, 絶食群では $125 \mu \mathrm{U} / \mathrm{ml}$ でF值は有意に増加した（Fig.2）。さら にインスリン濃度を $500 \mu \mathrm{U} / \mathrm{ml}$ まで上昇させると, 非絶食群, 絶食群とも F值は低下した。また, 絶食群 と非絶食群の比較では，インスリン濃度 $62.5 \mu \mathrm{U} / \mathrm{ml}$ で非絶食群（p<0.001）が，125 $\mu \mathrm{U} / \mathrm{ml}$ では絶食群 ( $\mathrm{p}<0.02)$ が有意な F值の高值を示した。さらに，ブドウ糖添加群と非添加群の比較では，インスリンの有 無に関係なく，ブドウ糖添加群でF值は高值を示した（p<0.001）。

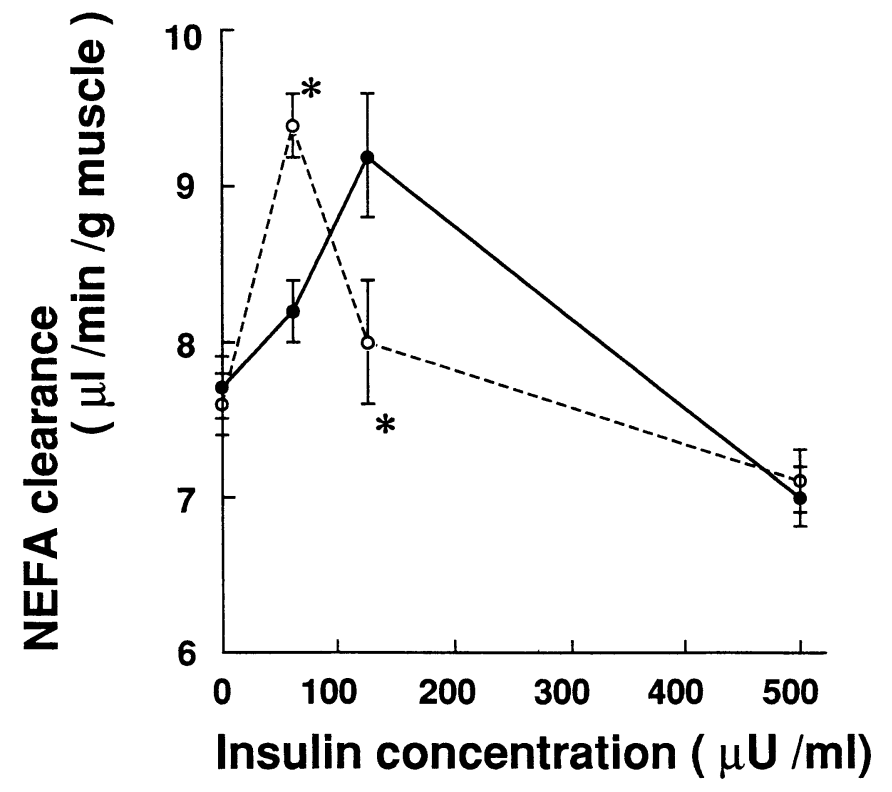

Fig. 2 The effect of insulin on NEFA utilization in the presence of $13.9 \mathrm{mM}$ glucose. Open and closed circles indicate non-starved and starved rats, respectively. $\left({ }^{*} \mathrm{p}<0.001\right.$ vs starved rats. $I$ mean \pm SEM) 
考

今回の検討では, 潅流液中のパルミチン酸濃度をその細胞内への取り込みが最大となる $1 \mathrm{mM} に$ 設定し10), NEFA利用の変化が細胞内のNEFA代謝によってのみ影響される条件下で実験を行った。

潅流液中にブドウ糖を添加しなかった絶食群で，F值が最も低值を示したこと，さらにブドウ糖添加群に おいては, 絶食群も速やかにF值は上昇し，かつインスリン非存在下ょりも一定のインスリン存在下でF值 が高值を示したことより，脂肪酸利用はブドウ糖供給低下の遷延した絶食状態よりも，絶食後の一定のブ ドウ糖供給下で一時的に促進される可能性が示唆された。Yki-Järvinenらは，インスリンクランプ法を用い, 骨格筋のブドウ糖利用に対するNEFAの影響を検討した結果，安静空腹時では，NEFAの上昇がブドウ糖利 用を促進することを示している11。その機序として，取り込まれた脂肪酸のre-esterificationに必要なエネル ギーとしてのブドウ糖利用が立進するためであると報告している。NEFAは脂肪細胞を含む末梢組織で，そ の $40 \%$ から $70 \%$ がre-esterificationに利用される ${ }^{122}$ 14)。よって本検討において，ブドウ糖供給の増加に伴い NEFA利用の克進が認められたのは，一定のブドウ糖供給の増加が，NEFAのre-esterificationに必要なエネ ルギーを供給し, re-esterificationが促進したため, あるいは, TCA cycleに供役して $\beta$ 酸化に必要なATPや $\mathrm{CoA}$ の供給が増加し， $\beta$ 酸化が充進したためと考えられた。いずれにしろ今回の結果は, Yki-Järvinenらの 成績を NEFA利用の立場から in vitroで支持するものと考えられる。

また，今回の成績では，絶食群と非絶食群の間で，ブドウ糖存在下のNEFA利用が最大となるインスリ ン濃度に差が認められた。我々は，絶食状態がブドウ糖利用におけるインスリン抵抗性をきたすことを，下 肢潅流実験法を用いてすでに報告している ${ }^{15)}$ 。絶食群と非絶食群との間で，NEFA利用が最大となるインス リン濃度にこのような差が認められたのは，インスリン刺激によるブドウ糖利用に差があるためと考えら れる。

しかし，ブドウ糖存在下で，インスリン濃度を $500 \mu \mathrm{U} / \mathrm{ml}$ まで上昇させると，絶食群，非絶食群とも脂 肪酸利用はむしろ抑制された。絶食および非絶食ラットを用いたブドウ糖存在下の下肢潅流実験では，イ ンスリン濃度に比例して，ブドウ糖利用が増加することがわかっている9)。大量に増加したブドウ糖供給は 解糖系を促進し，クエン酸の過剩産生をきたす。さらにacetyl-CoA carboxylaseの活性化を生じ， $\beta$ 酸化抑 制作用を有する malonyl CoA 増加させる ${ }^{16177}$ 。このような malonyl CoA や acetyl-CoA carboxylase の存在 は，骨格筋においても確認されており ${ }^{16181199}$ ，ブドウ糖と高濃度のインスリン存在下で認められたNEFA利 用の減少は，大量のブドウ糖供給により $\beta$ 酸化が抑制されたための变化であるとも考えられた。

結 語

安静時ラット下肢骨格筋においては，絶食後の一定のブドウ糖供給増加が，エネルギーとしてのNEFA利 用を促進した。さらに，大量のブドウ糖供給によりNEFA利用は抑制される可能性が示唆された。

文献

1) Randle PJ, Garland PB, Hales CN, Newsholome EA. The glucose fatty-acid cycle; its role of insulin sensitivity and the metabolic disturbances of diabetes mellitus. Lancet, 1963;i:785-9

2 ) Rennie MJ, Holloszy JO. Inhibition of glucose uptake and glycogenolysis by availability of oleate in well-oxygenated perfused skeletal muscle. Biochem J, 1977;168:161-70

3 ) Tiebaud D, DeFronzo RA, Jacot E, Golay A, Acheson K, Maeder E, Jequier E, Felber JP. Effect of long chain triglyceride infusion on glucose metabolism in man. Metabolism, 1982;31:1128-36

4 ) Ferrannini E, Barrett EJ, Bevilaccqua S, DeFronzo RA. Effect of fatty acids on glucose production and utilization in man. J Clin 
Invest, 1983;72:1737-47.

5 ) Issad T, Penicaud L, Ferre P, Kande J, Baudon MA, Girard J. Effect of fasting on tissue glucose utilization in conscious resting rats. Biochem J, 1987;246:241-4

6 ) Lee KU, Lee HK, Koh CS, Min HK. Artificial induction of intravascular lipolysis by lipid-heparin infusion leads to insulin resistance in man. Diabetologia, 1988;31:285-90

7) Felber JP, Haesler E, Jequier E. Metabolic origin of insulin resistance in obesity with and without type 2 (non-insulin-dependent) diabetes mellitus. Diabetologia, 1993;36:1221-9

8) Narimiya M, Azhar S, Dolkas CB, Mondon CE, Sims C, Wright DW, Reaven GM. Insulin resistance in older rats. Am J Physiol. 1984;246:E397-404

9) Narimiya M, Ohashi T, Kubokura T, Kaburagi M, Someya Y, Ikeda Y. Can plasma nonesterified fatty acid be regulators of the glucose utilization in the skeletal muscle? Endor J. 1994;41:197-206

10) Turcotte LP, Kines B, Richter EA. Saturation kinetics of palmitate uptake in perfused skeletal muscle. FEBS. 1990;279:327-9

11) Yki-Järvinen H, Puhakainen I, Koivisto VA. Effect of free fatty acids on glucose uptake and nonxidative glycolysis across human forearm tissues in the basal state and during insulin stimulation. J Clin Endocrinol Metab. 1991;72:1268-77

12) Bonadona RC, Groop LC, Zych K, Shank M, Defronzo RA. Dose-dependent effect of insulin on plasma free fatty acid turnover and oxidation in humans. Am J Physiol 1990;259:E36-50

13) Wolfe RR, Klein S, Carraro F, Weber J-M. Role of triglyceride-fatty acid cycle in controlling fat metabolism in humans during and after exercise. Am J Physiol 1990;258:E382-9

14) Groop LC, Bonadona RC, Shank M, Petrides AS, DeFronzo RA. Role of free fatty acids and insulin determining free fatty acid and lipid oxidation in man. J Clin Invest 1991;87:83-9

15) Ohashi T, Narimiya M, Kaburagi M, Kubokura T, Someya Y, Ikeda Y, Isogai Y. Effects of non-esterfied fatty acids on glucose utilization in the starved rat skeletal muscle. Jikeikai Med J. 1994;41:55-61

16) Bianchi A, Evans JL, Iverson AJ, Nordlund AC, Watts TD, Witters LA. Identification of an isozymic form of acetyl-CoA carboxylase. J Biol Chem. 1990;265:1502-9

17) Witters LA, Nordlund AC, Marshall L. Regulation of intracellular acetyl-CoA carboxylase by ATP depletors mimics the action of the 5'-AMP-activated protein kinase. Biochem Biophys Res Commun. 1991;181:1486-92

18) McGarry JD, Mills SE, Long CS, Foster DW. Observations on the affinity for carnitine, and malonyl-CoA of carnitine palmitoyl transferase I in animal and human tissue. Biochem J. 1983;214:21-8

19) Mills SE, Foster DW, McGarry JD. Interaction of malonyl-CoA and related compounds with mitochondria from different rat tissues. Biochem J. 1983;214:83-91

(受付日：'94. 2.25)

(採択日：'94.11.7) 